\section{THE ALIEN WITHIN, OR THE TRULY ARTIFICIAL NATURE OF HUMAN INTELLIGENCE. A RESPONSE TO ANNE DIPPEL'S METAPHORS WE LIVE BY. THREE COMMENTARIES ON ARTIFICIAL INTELLIGENCE AND THE HUMAN CONDITION}

\author{
Gabriela Méndez Cota \\ Universidad Iberoamericana Ciudad de México
}

In this invited response to Anne Dippel's chapter about the metaphors at work in the latest mainstream investments in artificial intelligence, I would ultimately like to dwell on the author's statement that artificial intelligence «should be seen for what it truly is, a technological alien» (Dippel, 2019: 39). Is this an ontological and normative statement about what it means to be human? Does it mean that humans in general should today preserve a sense of themselves as prior to, and therefore rigorously distinct from, artificial intelligence in general? It seems to me that Dippel's position is ambiguous on this point, and I would merely like to suggest that a nonnormative ethics of the human as always already technological could perform well as a critical supplement to Dippel's politically important distinction between the embodied, biological processes at work in human intelligence on the one hand, and the disembodied masculinist fantasies at work in mainstream Al narratives on the other hand. To this end, I will first try to fairly reconstruct Dippel's argument and to introduce, along the way, my own concern, summed up in the title of this commentary, with the problematic metaphoricity, hence artificiality, partiality and responsibility of any intelligent critique of artificial intelligence. Towards the conclusion I will bring into the discussion another recent publication on current Al stories and metaphors, namely, Al Art. Machine Visions and Warped Dreams by media theorist and artist Joanna Zylinska (2020), who has been working for more than a decade on a nonhumanist feminist bioethics for the age of new media and technoscience.

In the first of her three commentaries, Dippel writes that "any comparison of human and artificial intelligence must be considered bizarre if not utterly pointless at best» (Dippel, 2019: 35). Such an intuitive claim is made in the context of an autoethnographic approach that works at building the standpoint of a feminist mother, from which it becomes imperative to argue that «it is the politics of embodied care (Hamington 2001), or the politics of care in technoscience (Martin, Myer, Viseu 2015), that needs to be brought into a larger social conversation on artificial intelligence and its relation to what it means to be human» (Dippel, 2019: 35). Thus, in the end for Dippel any 
comparison of human and artificial intelligence must be considered not merely bizarre or pointless, but in fact morally and politically dangerous because the oversimplified and disembodied understanding of intelligence in actual $\mathrm{Al}$ research -as computing power, data storage capacity, pattern recognition, statistical analysis and so forth- risks dismissing "the significance of being a responsible human agent altogether»(Dippel, 2019: 35). Even if one agrees that the meaning and significance of human intelligence have to do with taking responsibility, with taking care, one can still ask whether the question of framing intelligence through taking care and responsibility can be adequately addressed today within the framework of the infant and their mother, given this framework's rather problematic history and metaphoric load. As Anne Dippel argues, words and metaphors have power, so one could at least ask how specific notions of motherhood and care influence perceptions of what it means to be human in the face of artificial intelligence and other technoscientific projects.

As Dippel's sources acknowledge, from its early emphasis on motherhood and infant care, care literature has slowly but steadily developed into a more intersectional and geographically decentered set of debates that exceeds the original focus, now widely regarded as White and middle-class, on the nurturant sort of care which motherhood in general stands for. Care literature today addresses the many kinds of dirty work that, often for the lack of an intersectional analysis (Hankivsky, 2014), do not get recognition as care, however essential they might be for the maintenance and reproduction of human life. What if we asked the question of what it means to be human from the standpoint of such dirty work, that is, from the kind of infrastructural work that is performed by specific groups of subordinate humans, but also by machines and other non-human forms of life? Moreover, what if we asked about intelligence as something that perhaps cannot be reduced to a property of individual organisms and that might instead be better understood through the study of complex material-semiotic situations in which morethan-human issues and power relations are at stake? These questions are unavoidable, it seems to me, in so far as they belong to the wider trajectory of feminist theory through which, among other things, care ethics has become radicalized as intersectional analysis of infrastructural processes and in which feminist epistemologies (Alcoff and Potter, 1993) have become radicalized through feminist science studies (Harding, 1991), technoscience feminism (Åsberg and Braidotti, 2018) and feminist posthumanities more generally. But they are also unavoidable in the context of the coronavirus pandemic, where differentially positioned scientists, public servants, healthcare workers around the world struggle and collaborate with numerous technologies, including artificial intelligence applications, to bring the viral other under control.

Certainly, Dippel's subsequent commentaries on mainstream artificial intelligence research, which have an ethnographic basis and a sharp theoretical focus, enrich the cross-disciplinary work of feminist thinking with technoscience, by documenting empirically and clarifying the specific ways in which the current development of evolutionary algorithms attempts to symbolically resuscitate "Man of Reason» (Lloyd, 2002) or the abstract, disembodied, irresponsible subject of knowledge that feminist epistemologies, among other strands of feminist philosophy, had thoroughly demolished by the end of the 20th century. Demolition would appear to be necessary once again because, as Dippel notes, the feminist critique of Man, "for example in media studies or philosophy, i.e. disciplines, that reflect on the mediatedness of contemporary knowledge in natural sciences", continues to develop in segregation from mainstream science and technological development. Meanwhile, actual scientists and engineers continue to dream of the day when humans will "live eternally, free from fear and illness, as cyborgs enhanced by artificial intelligence» (Dippel, 2019: 37). But what is perhaps most incisive in Dippel's contribution takes the form of a diagnosis around the current specificity of such a masculine dream of transcendence. Not only is its underlying assumption that "[h]umans are the standard that serves for technology as the main criterion in terms of intelligence» (Dippel, 2019: 38), but it is a rather particular vision of what humans are -and therefore what human intelligence amounts to -that serves as a standard for dreaming about and engaging with artificial intelligence. It is an elitist vision of humans as narrowly rational, calculative agents with no embodied moral consciousness or any understanding of their own possible death -so 
memorably depicted, by the way, in Adam Curtis's documentary The Trap (2007) 1 - that informs the neoliberal images of human triumph and success as well as the images of technoscientific salvation which only machine players, such as Deep Blue and AlphaGo, can apparently fulfil. Against such a metaphorical counterpart of actual needy and mortal humanity Dippel forcefully argues that « $[r]$ esearchers, politicians, the private sector and public opinion need to come to the point of communalization and people's empowerment of artificial intelligence, which may be difficult imagine in the current political and economical system» (Dippel, 2019: 40).

I am in strong agreement with Dippel's feminist critique of Al metaphors of intelligence, evolution, and play, as I am with her broader injunction to democratize and communalize $\mathrm{Al}$, no matter how improbable this currently appears to be. However, I would like to also offer an alternative, non-humanist, take on Dippel's moral request that we see artificial intelligence "for what it truly is, a technological alien» (Dippel, 2019: 39). Having already suggested that we explicitly consider the well-known limitations of thinking human intelligence and care responsibilities through the gendered frameworks of human reproduction, I would suggest it is important to openly ask how the very notion of the human is time and again constituted through a rhetorical opposition between humanity (the family) and the machine (the alien). What gets lost, what remains unaccounted for, when one takes this rhetorical opposition as some sort of self-evident truth, for example by drawing on the still hegemonic equation of womanhood with motherhood? Besides the dirty work that some humans perform alongside machines for the benefit of normalized conceptions of the human, what gets lost is the kind of technical artifice, which is political imagination, that might make possible more critical and creative paths for becoming with Artificial Intelligence. In short, what gets lost is the who, the how, and the what for of «communalization and people's empowerment» (Dippel, 2019: 40).

At some point in her chapter, Anne Dippel seems to gloss over the long-term contributions of Donna Haraway's cyborg feminism by associating the cyborg image in general with an inclusive version of artificial intelligence that ignores the political sphere and the social consequences of Al. This is unfortunate given Haraway's rich, complex and multi-faceted critique of scientific metaphors, as well as her enduring commitment to situated, embodied, oppositional storytelling in the service of a radical democratization of technoscience, and more recently in the service of a non-reproductive, multi-species reimagination of care and modest survival through critical, that is, noninnocent, technoscientific collaborations (Haraway, 2016). Partly in acknowledgment of Haraway's work, which belongs to the living legacy of technoscience feminism more generally, Joanna Zylinska's recent book on Al Art (2020) invites us -cultural critics of science and technology- to consider the specific role of artistic and literary approaches in facing up ethically and politically to the latest techno-hype. Zylinska shares Dippel's diagnosis that «capitalfuelled human thinking on Al itself manifests a rather narrow set of intelligence markers, which are premised on a truncated, disembodied and yet sovery-gendered model of human subjectivity". Al, she goes on, is indeed premised on "hydrophobia, i.e. wariness of the material or, better, elemental side of media technology" (Zylinska, 2020: 41). Yet instead of pitching the human (mother or child) against the machine, Zylinska proposes «to see different forms of human activity, including art, as having always been technical, and thus also, to some extent, artificially intelligent» (Zylinska, 2020: 13).

From the standpoint of a feminist practitioner of the posthumanities, I would argue that bringing the politics of care in technoscience to the larger social conversation requires a non-rationalist approach to politics as well as a non-normative ethics of the human as always already artificially intelligent. As Zylinska points out, "the very concept of artificial intelligence is premised on artifice, which in its Latin etymology (artificium) goes beyond the current meaning of deception and trickery to signal art, craft, and skill» (Zylinska, 2020: 32). To understand the human condition in this way is not to feed dreams of cyborg transcendence as long as art, craft, and skill are regarded as material, precarious, and power-ridden. If, in this sense, humans are indeed «quintessentially technical beings» (Zylinska, 2020: 27), how does such a perspective call for better stories and better questions in the face of the current Al techno-hype?

1 The Trap: What Happened to Our Dream of Freedom is a BBC television documentary series which explores the modern concept and definition of freedom. It consists of three 60-minute programmes: chapter 1 Fuck you, buddy; chapter 2 The Lonely Robot; and chapter 3 We will force you to be free. 
Throughout her book Zylinska examines Al art's potential, as well as its limitations and its ideological pitfalls, in the task of demystifying technoscientific narratives by highlighting social and political issues around "creativity, intelligence, perception and the role and position of the human in the world including questions of labour, robotisation and the long-term survival of the human species» (Zylinska, 2020: 17). While this is not the place for an extended review of Zylinska's book, I merely want to offer it here as a critical supplement to Dippel's notion of artificial intelligence as a technological alien. Once we acknowledge that the alien is within, that it is already in a broader social conversation that takes the form of «a confluence of technical and cultural changes, industry claims, popular anxieties, moral panics and creative interventions across different media and platforms» (Zylinska, 2020: 35), an non-determined we is able to emerge through each instance of questioning, through multiple material-semiotic registers: «Whose brainchild (and bodychild) is the Al of today? Who and what does Al make life better for? Who and what can't it see?» (Zylinska, 2020: 29).

\section{REFERENCES}

Åsberg, Cecilia and Braidotti, Rosi (eds.) (2018). A Feminist Companion to the Posthumanities. Cham: Springer.

Alcoff, Linda and Potter, Elizabeth (eds.) (1993). Feminist Epistemologies. Nueva York y Londres: Routledge.

Dippel, Anne (2019). Metaphors We Live By. Three Commentaries on Artificial Intelligence and the Human Condition. In Andreas Sudmann (ed.).
The Democratization of Artificial Intelligence: Net Politics in the Era of Learning Algorithms. Bielefeld: Transcript Verlag, pp. 33-42.

Hankivsky, Olena (2014). Rethinking Care Ethics: On the Promise and Potential of an Intersectional Analysis. American Political Science Review, 108 (2): 252264. doi:10.1017/S0003055414000094

Haraway, Donna J. (2016). Staying with the Trouble: Making Kin in the Chthulucene. Durham: Duke University Press.
Harding, Sandra (1991). Whose Science, Whose Knowledge?: Thinking from Women's Lives. Ithaca: Cornell University Press.

Lloyd, Genevieve (2004). The Man of Reason: "Male" and "Female" in Western Philosophy. London: Routledge.

Zylinska, Joanna (2020). Al Art: Machine Visions and Warped Dreams. London: Open Humanities Press. 